\section{(- OPEN ACCESS}

\title{
Gitelman syndrome and primary hyperparathyroidism: a rare association
}

\author{
Teresa Rego, ${ }^{1}$ Fernando Fonseca, ${ }^{1}$ Rita Cerqueira, ${ }^{2}$ Ana Agapito ${ }^{1}$
}

${ }^{1}$ Department of Endocrinology, Hospital Curry Cabral, Lisboa, Portugal

${ }^{2}$ CGC Genetics, Molecular Diagnostics and Clinical Genomics, CGC Genetics, Porto, Portugal, Porto, Portugal

Correspondence to Dr Ana Agapito, amagapito@chlc.min-saude.pt

Accepted 29 April 2018

Check for updates

To cite: Rego T, Fonseca $\mathrm{F}_{\text {, }}$ Cerqueira R, et al. BMJ Case Rep Published Online First: [please include Day Month Year]. doi:10.1136/bcr-2017223663

\section{SUMMARY}

Gitelman syndrome(GS) is a rare autosomal recessive salt-losing tubulopathy of young adults, characterised by hypokalaemia, hypomagnesaemia, hypocalciuria and secondary hyperaldosteronism. Hypercalcaemia due to hypocalciuria in these patients is extremely rare. A 25-year-old healthy woman was referred to the Endocrinology clinic for evaluation of persistent hypokalaemia. She presented with fatigue, myalgias, cramps and paraesthesia. Her physical examination was normal. Laboratory workup revealed: $\mathrm{K}^{+} 2.7 \mathrm{mEq} / \mathrm{L}$ (r.v.3.5-5.1), 24 hours urinary $\mathrm{K}^{+} 84.7 \mathrm{mEq} / 24$ hours (r.v.25-125), $\mathrm{Mg}^{2+} 0.71 \mathrm{mg} / \mathrm{dL}$ (r.v.1.6-2.6), 24 hours urinary $\mathrm{Mg}^{2+} 143.1 \mathrm{mg} / 24$ hours (r.v.73-122), $\mathrm{Ca}^{2+} 12$ $\mathrm{mg} / \mathrm{dL}$ (r.v.8.4-10.2), aldosterone $47.1 \mathrm{ng} / \mathrm{mL}$ (r.v. 4-31) and active renin $374.7 \mathrm{uUI} / \mathrm{mL}$ (r.v.4.4-46.1). She was diagnosed with GS and was treated with spironolactone, oral $\mathrm{K}^{+}$and $\mathrm{Mg}^{2+}$ supplementation. Further investigation confirmed hypercalcaemia due to primary hyperparathyroidism owing to a single parathyroid adenoma. Following parathyroidectomy serum calcium normalised.

Current knowledge favours that hypomagnesaemia in patients with GS protects them from hypercalcaemia. In this context of multiple electrolyte imbalances, correction of hypomagnesaemia is a challenge and should be done carefully. Like in our patient, aetiology of hypercalcaemia should be promptly diagnosed and reversed.

\section{BACKGROUND}

Gitelman syndrome (GS) was first described in 1966 in a family characterised by hypokalaemia, hypomagnesaemia, hypocalciuria, metabolic alkalosis and hyper-reninemic hyperaldosteronism. It is a rare autosomal recessive salt-losing tubulopathy with a prevalence estimated at approximately $1: 40.000 .^{2}$ It is caused by mutations of SLC12A3 gene that encodes the sodium chloride cotransporter (NCC) and magnesium channels in the thiazide-sensitive segment of the renal distal convoluted tubule. $^{3}$

GS is usually diagnosed during adolescence or adulthood and the clinical spectrum is wide, ranging from asymptomatic to severe manifestations, such as episodes of paralysis, seizures or cardiac arrhythmias. Symptoms are related to electrolyte abnormalities; however, its severity does not correlate with the intensity of symptoms. ${ }^{4}$ Moreover, the phenotype-genotype correlation is heterogeneous, since different phenotypes have been reported in family members presenting identical genetic defects. ${ }^{5}$
Hypocalciuria is a prominent feature in $\mathrm{GS}^{16}$; nevertheless, the total plasma calcium concentration has been reported to be normal. ${ }^{16}$ Rarely, slight hypercalcaemia can occur in the course of GS due to dehydration-induced hyperproteinaemia. ${ }^{6}$ Thereby, the presence of hypercalcaemia in the course of this disease should require further investigation.

Herein, we describe a rare case of GS associated with moderate to severe hypercalcaemia resulting in profound electrolyte imbalance. We also intend to report our apprehension in initial control of severe hypomagnesaemia in a patient with concomitant hypercalcaemia.

\section{CASE PRESENTATION}

A 25 -year-old Caucasian normotensive woman was admitted to the emergency department in June 2015 due to malaise, fatigue, myalgias, cramps, left hemiface and left upper arm paraesthesias. Head CT excluded intracranial lesions and blood tests revealed a low serum $\mathrm{K}^{+}$of $2.9 \mathrm{mEq} / \mathrm{L}$. She was referred to the Endocrinology clinic for evaluation of persistent hypokalaemia. She denied diarrhoea, abuse of diuretics, laxatives or 'natural supplements'. Concerning her family history, she has no siblings, her parents are non-consanguineous and healthy. Physical examination revealed depressed humour, normal body mass index $(22 \mathrm{~kg} /$ $\mathrm{m}^{2}$ ), blood pressure $110 / 80 \mathrm{~mm} \mathrm{Hg}$, pulse rate 82 bpm, no stigmata of hypercortisolism and no focal neurological signs.

\section{INVESTIGATIONS}

The patient's laboratory findings are shown in tables 1 and 2 .

She presented with secondary hyperaldosteronism, renal wasting resulting in hypokalaemia and hypomagnesaemia. These laboratory findings associated with her normotensive profile favoured the diagnosis of GS. She was provided with a low dose of magnesium aspartate $(500 \mathrm{mg} /$ day $)$ and oral potassium chloride progressively adjusted to $600 \mathrm{mg} 4$ id with improvement of the symptoms

The severity of hypercalcaemia did not seem to be justified by hypocalciuria of GS; furthermore, hypophosphataemia did not fit in this context. Additional tests revealed $\mathrm{Ca}^{2+} 11.8 \mathrm{mg} / \mathrm{dL}$, Pi $1.9 \mathrm{mg} / \mathrm{dL}$, PTH107.3 pg/mL (n.r. 14.8-83.1) and $25 \mathrm{OH}$ vitamin D $20.4 \mathrm{ng} / \mathrm{mL}$ (n.r. 4.8-52.8) that were consistent with hypercalcaemia due to primary hyperparathyroidism (PHPT). Abdominal CT scan excluded renal lesions, such nephrolithiasis. Urinary 
Unusual association of diseases/symptoms

\begin{tabular}{|c|c|c|}
\hline & & Normal range \\
\hline Haemoglobin & $12.9 \mathrm{~g} / \mathrm{L}$ & $12-15$ \\
\hline Leucocytes & $11.90 \times 10^{\wedge} 9 / \mathrm{L}$ & $4.5-11$ \\
\hline Platelets & $317 \times 10^{\wedge} 9 / \mathrm{L}$ & $150-450$ \\
\hline Glucose & $69 \mathrm{mg} / \mathrm{dL}$ & $60-100$ \\
\hline Urea & $27 \mathrm{mg} / \mathrm{dL}$ & $15-40$ \\
\hline Creatinine & $0.57 \mathrm{mg} / \mathrm{dL}$ & $0.57-1.11$ \\
\hline \multicolumn{3}{|l|}{$\begin{array}{l}\text { Glomerular filtration rate } \\
(\text { GFR })>60 \mathrm{~mL} / \mathrm{min}\end{array}$} \\
\hline Total proteins/albumin & $74 \mathrm{~g} / \mathrm{L}$ & $60-83$ \\
\hline Sodium $\left(\mathrm{Na}^{+}\right)$ & $139 \mathrm{mEq} / \mathrm{L}$ & $136-145$ \\
\hline Potassium $\left(\mathrm{K}^{+}\right)$ & $2.7 \mathrm{mEq} / \mathrm{L}$ & $3.5-5.1$ \\
\hline Chloride $\left(\mathrm{Cl}^{-}\right)$ & $97 \mathrm{mEq} / \mathrm{L}$ & $98-107$ \\
\hline Calcium $\left(\mathrm{Ca}^{2+}\right)$ & $12 \mathrm{mg} / \mathrm{dL}$ & $8.4-10.2$ \\
\hline Phosphorus (Pi) & $1.6 \mathrm{mg} / \mathrm{dL}$ & $2.3-4.7$ \\
\hline Magnesium $\left(\mathrm{Mg}^{2+)}\right.$ & $0.71 \mathrm{mg} / \mathrm{dL}$ & $1.6-2.6$ \\
\hline Total cholesterol & $254 \mathrm{mg} / \mathrm{dL}$ & $<190$ \\
\hline Aldosterone & $47.1 \mathrm{ng} / \mathrm{mL}$ & $4-31$ \\
\hline Active renin & $374.7 \mathrm{uUl} / \mathrm{mL}$ & $4.4-46.1$ \\
\hline
\end{tabular}

\begin{tabular}{lll}
\hline & Table 2 & Laboratory results-24-hour urine (vol. 2300 mL) \\
\hline & & Normal range \\
\hline $\mathrm{K}^{+}$ & $84.7 \mathrm{mEq} / 24$ hours & $25-125$ \\
$\mathrm{Mg}^{2+}$ & $143.1 \mathrm{mg} / 24$ hours & $73-122$ \\
$\mathrm{Ca}^{2+}$ & $133 \mathrm{mg} / 24$ hours & $100-300$ \\
$\mathrm{Pi}$ & $1.1 \mathrm{~g} / 24$ hours & $0.4-1.3$ \\
\hline
\end{tabular}

The occurrence of PHPT in a young patient also justified DNA analysis of HRPT2 and MEN1 genes that were both normal in this case.

\section{TREATMENT}

An inferior left parathyroidectomy was performed and histological study confirmed the diagnosis of parathyroid adenoma.

\section{OUTCOME AND FOLLOW-UP}

Serum $\mathrm{Ca}^{2+}$ and PTH normalised after surgery $\left(\mathrm{Ca}^{2+} 9.7 \mathrm{mg} / \mathrm{dL}\right.$, PTH $5 \mathrm{pg} / \mathrm{mL}$ and Pi $4.8 \mathrm{mg} / \mathrm{dL}$ ). Hypocalciuria emerged and in 17 months of follow-up normocalcaemia persists (table 3 ). She maintained mild symptomatic hypokalaemia on oral $\mathrm{KCl} 600 \mathrm{mg}$ 6id, thus spironolactone $100 \mathrm{mg} /$ day was prescribed. During the last 6 months, medicated with spironolactone $100 \mathrm{mg} /$ day, $\mathrm{KCl}$ $600 \mathrm{mg} 2 \mathrm{id}$, magnesium aspartate $1229.6 \mathrm{mg} 4 \mathrm{id}$, she presented serum $\mathrm{K}^{+}$in the inferior limit of normal range. She maintains mild-to-moderate hypomagnesaemia which can be explained by poor medication adherence due to gastrointestinal intolerance (table 3). The patient keeps regular follow-up in our department with clinical and biochemical evaluation.

\section{DISCUSSION}

GS is linked to inactivating mutations in the SLC12A3 gene resulting in loss of function of the encoded NCC in the distal convoluted tubules. The clinical and biochemical picture of patients with GS resemble those who are on thiazide diuretics, given that the affected transporter is the exact target of thiazides. ${ }^{4}$ pathogenicity.

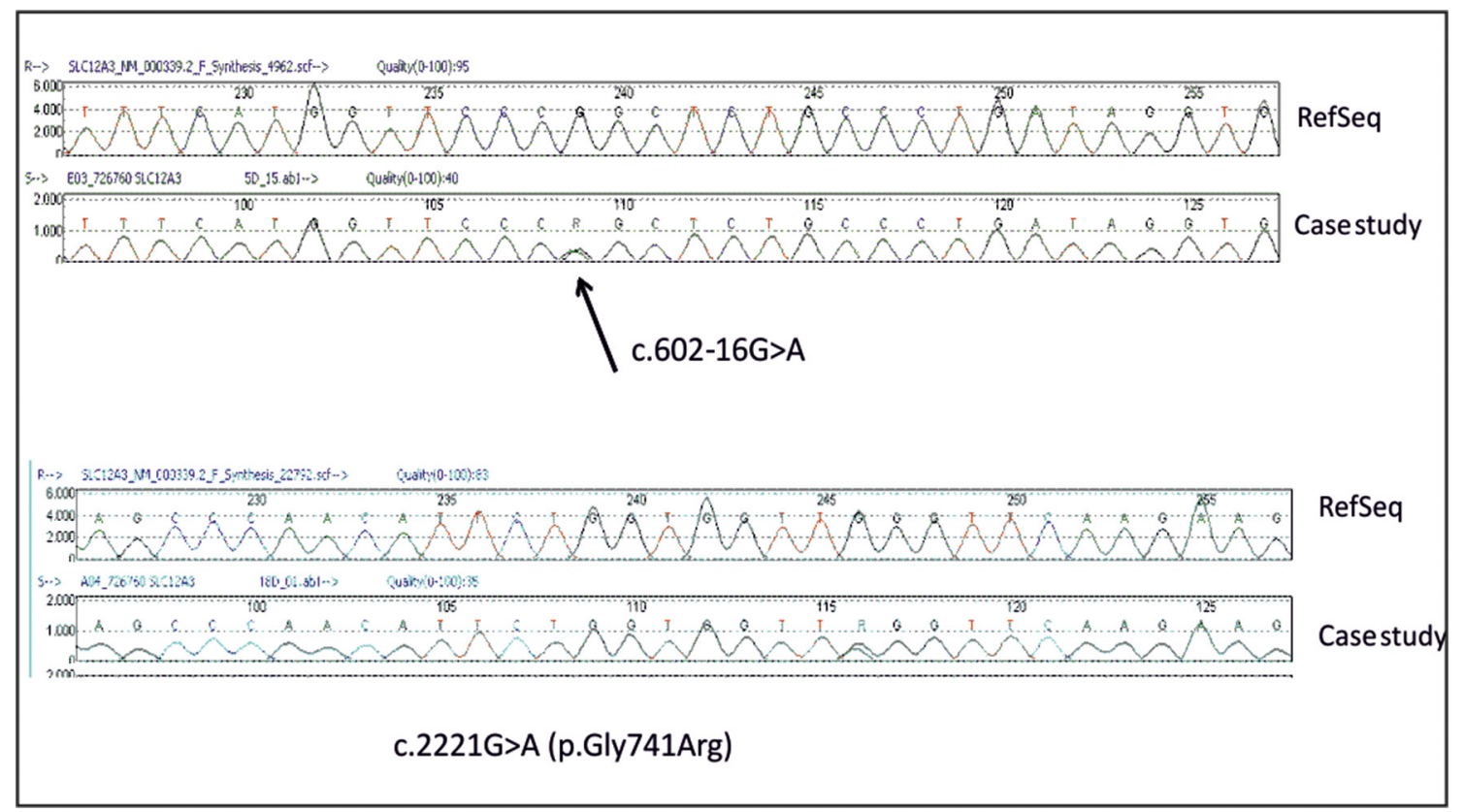

Figure 1 Chromatographe of the sequence: above: representation of variant c.602-16G>A; below: representation of variant c.2221G $>A$ (p.Gly741Arg), both detect in SLC12A3 gene. 
Table 3 Laboratory tests (August 2016)

\begin{tabular}{lll}
\hline & & Normal range \\
\hline $\mathrm{Ca}^{2+}$ & $9.9 \mathrm{mg} / \mathrm{dL}$ & $8.4-10.2$ \\
24 hours urine $\mathrm{Ca}^{2+}$ & $<53 \mathrm{mg} / 24$ hours & $100-300$ \\
$\mathrm{Pi}$ & $2.9 \mathrm{mg} / \mathrm{dL}$ & $2.3-4.7$ \\
$\mathrm{Mg}^{2+}$ & $1.09 \mathrm{mg} / \mathrm{dL}$ & $1.6-2.6$ \\
\hline Parathyroid hormone (PTH) & $14.9 \mathrm{pg} / \mathrm{mL}$ & $14.76-83.1$ \\
$25 \mathrm{OH}$ vitamin D & $35 \mathrm{ng} / \mathrm{mL}$ & $4.8-52.8$ \\
$\mathrm{Na}^{+}$ & $137 \mathrm{mEq} / \mathrm{L}$ & $136-145$ \\
$\mathrm{~K}^{+}$ & $3.6 \mathrm{mEq} / \mathrm{L}$ & $3.5-5.1$ \\
$\mathrm{Cl}^{-}$ & $97 \mathrm{mEq} / \mathrm{L}$ & $98-107$ \\
\hline
\end{tabular}

Despite clinical and biochemical similarities between patients with GS and those on thiazide diuretic therapy, ${ }^{4}$ the presence of hypercalcaemia in the former group is unusual. ${ }^{15}$ This fact can be explained by impaired calciotropic hormones due hypomagnesaemia in patients with GS. ${ }^{6}$ Bianchetti et al demonstrated a blunted relationship between PTH, ionised calcium concentration and calcitriol in patients with GS providing evidence that these patients have a disturbed secretion of PTH. ${ }^{6}$ Moreover in GS, normal levels of both plasma phosphate and urinary fractional phosphate excretion rule out PTH hyperfunction. ${ }^{4}$

We described a rare case of a young woman with GS presenting with hypercalcaemia due to PHPT. In PHPT, hypercalcaemia results from inappropriate hypersecretion of PTH from parathyroid gland(s). PTH increases tubular reabsorption of calcium in the kidney, stimulates release of skeletal calcium stores and upregulates $1 \alpha$ - hydroxylase resulting in increased 1,25- $(\mathrm{OH}) 2 \mathrm{D} 3$ production and intestinal calcium absorption. ${ }^{8}$

The differential diagnosis between PHPT and familial hypocalciuric hypercalcaemia should be considered because the latter is a benign condition. In a patient with GS, this differentiation is difficult because of inherent hypocalciuria. In our patient, the diagnosis of PHTP was sustained by concomitant hypophosphataemia, high levels of PTH, unexpected 'normal calciuria' and the findings in neck ultrasonography. The normalisation of calcium values after parathyroidectomy also firms this hypothesis.

Genetic study of our patient detected the variant c.602-16G $>$ A and the variant c. $2221 \mathrm{G}>\mathrm{A}$ (p.Gly741Arg), both in heterozygosity, in SLC12A3 gene. The variant c.2221G>A (p.Gly741Arg) was described in other patients with GS ${ }^{910}$ and is found on dbSNP and ExAC databases with a global frequency of $0.040 \%$. It is localised in a highly conserved residue and its functional impact was already studied. Thus, it should be considered a probably pathogenic variant. The variant c.602-16G $>\mathrm{A}$ is described on the database of HGMD; as a disease-causing mutation, ${ }^{11}$ it has been identified in two different families with GS, in trans with other pathogenic mutations. It is also described in dbSNP and ExAC databases with a frequency of $0.0016 \%$. However, due to lack of functional studies confirming the splicing effect, this variant is considered of undetermined significance.

Genetic study of the parents revealed in the father the variant c.602-16G >A and the mother the variant c.2221G>A (p.Gly741Arg), in SLC12A3 gene. The genetic study of the parents concluded that the variants found are in different alleles (trans), which reinforce their pathogenicity.

GS is a recessively inherited disease, with simple heterozygous relatives being asymptomatic. Nevertheless, there is a small percentage of affected individuals with only one mutant allele. $^{12}$ Since the expression of NCC may be influenced by epigenetic modifications and/or silent polymorphisms, this may lead to impaired function in simple heterozygous. ${ }^{12}$ Screening of electrolyte abnormalities in parents was done and excluded a mild phenotype.

The combination of hypokalaemia, hypomagnesaemia and hypercalcaemia is uncommon but potentially lethal. To our knowledge, there is only one case reported in the literature. In our patient, initial severe hypomagnesaemia imposed carefully $\mathrm{Mg}^{2+}$ reposition, taking into account the risk of worsening hypercalcaemia and justified strictly electrolytic monitoring.

Molecular study added value since permits the screening of the parents and genetic counselling when pregnancy is desired.

\section{Learning points}

Gitelman syndrome (GS) is caused by mutations in the $S L C 12 A 3$ gene.

- It is a rare autosomal recessive tubulopathy characterised by hypokalaemia, hypomagnesaemia, hypocalciuria, metabolic alkalosis and secondary hyperaldosteronism.

- Hypercalcaemia due to hypocalciuria in these patients is extremely rare. This can be explained by impaired calciotropic hormones due to hypomagnesaemia observed in these patients.

- The presence of hypercalcaemia in the course of GS requires further evaluation in order to exclude reversible causes of hypercalcaemia.

Contributors All authors have substantially contributed for the conception and the design of this manuscript. TR has collected all the data, performed the required analysis and drafted the article. TR and FF are the clinicians who have observed the patient. FF, RC and AG performed a critical revision of the article. RC, MT and JPB performed the genetic study. All authors approved the final version to be published.

Funding The authors have not declared a specific grant for this research from any funding agency in the public, commercial or not-for-profit sectors.

Competing interests None declared.

Patient consent Obtained.

Provenance and peer review Not commissioned; externally peer reviewed.

Open Access This is an Open Access article distributed in accordance with the Creative Commons Attribution Non Commercial (CC BY-NC 4.0) license, which permits others to distribute, remix, adapt, build upon this work non-commercially, and license their derivative works on different terms, provided the original work is properly cited and the use is non-commercial. See: http://creativecommons.org/ licenses/by-nc/4.0/

(C) BMJ Publishing Group Ltd (unless otherwise stated in the text of the article) 2018. All rights reserved. No commercial use is permitted unless otherwise expressly granted.

\section{REFERENCES}

1 Gitelman HJ, Graham JB, Welt LG. A new familial disorder characterized by hypokalemia, hypomagnesemia. Trans Assoc Am Physiol 1966;79:221-35.

2 Knoers NV, Levtchenko EN. Gitelman syndrome. Orphanet J Rare Dis 2008;3:22.

3 Scheinman SJ, Guay-Woodford LM, Thakker RV, et al. Genetic disorders of renal electrolyte transport. N Engl J Med 1999;340:1177-87.

4 Graziani G, Fedeli C, Moroni L, et al. Gitelman syndrome: pathophysiological and clinical aspects. QJM 2010;103:741-8.

5 Lin SH, Cheng NL, Hsu YJ, et al. Intrafamilial phenotype variability in patients with Gitelman syndrome having the same mutations in their thiazide-sensitive sodium/ chloride cotransporter. Am J Kidney Dis 2004;43:304-12.

6 Bianchetti MG, Bettinelli A, Casez JP, et al. Evidence for disturbed regulation of calciotropic hormone metabolism in gitelman syndrome. J Clin Endocrinol Metab 1995;80:224-8.

7 Wen YK. An unusual case of Gitelman's syndrome with hypercalcemia. Ren Fail 2012;34:241-3.

8 Fraser WD. Hyperparathyroidism. The Lancet 2009;374:145-58. 


\section{Unusual association of diseases/symptoms}

9 Simon DB, Nelson-Williams C, Bia MJ, et al. Gitelman's variant of Bartter's syndrome, inherited hypokalaemic alkalosis, is caused by mutations in the thiazide-sensitive $\mathrm{Na}$ Cl cotransporter. Nat Genet 1996;12:24-30.

10 De Jong JC, Van Der Vliet WA, Van Den Heuvel LP, et al. Functional expression of mutations in the human $\mathrm{NaCl}$ cotransporter: evidence for impaired routing mechanisms in Gitelman's syndrome. J Am Soc Nephrol 2002;13:1442-8.
11 Glaudemans B, Yntema HG, San-Cristobal P, et al. Novel NCC mutants and functional analysis in a new cohort of patients with Gitelman syndrome. Eur J Hum Genet 2012;20:263-70.

12 Xia MF, Bian H, Liu H, et al. Hypokalemia, hypomagnesemia, hypocalciuria, and recurrent tetany: Gitelman syndrome in a Chinese pedigree and literature review. Clin Case Rep 2017:5:578-86.

Copyright 2018 BMJ Publishing Group. All rights reserved. For permission to reuse any of this content visit http://group.bmj.com/group/rights-licensing/permissions.

BMJ Case Report Fellows may re-use this article for personal use and teaching without any further permission.

Become a Fellow of BMJ Case Reports today and you can:

- Submit as many cases as you like

- Enjoy fast sympathetic peer review and rapid publication of accepted articles

- Access all the published articles

Re-use any of the published material for personal use and teaching without further permission

For information on Institutional Fellowships contact consortiasales@bmjgroup.com

Visit casereports.bmj.com for more articles like this and to become a Fellow 